\title{
Front Matter: Volume 8649
}

, "Front Matter: Volume 8649," Proc. SPIE 8649, The Engineering Reality of Virtual Reality 2013, 864901 (4 March 2013); doi: 10.1117/12.2025893

SPIE Event: IS\&T/SPIE Electronic Imaging, 2013, Burlingame, California, United SPIE. States 
PROCEEDINGS

IS\&T / SPIE

Electronic

Imaging

SCIENCE AND TECHNOLOGY

\section{The Engineering Reality of Virtual Reality 2013}

Margaret Dolinsky

Ian E. McDowall

Editors

4-5 February 2013

Burlingame, California, United States

Sponsored by

IS\&T-The Society for Imaging Science and Technology

SPIE

Coponsored by

Qualcomm Inc. (United States)

Published by

SPIE 
The papers included in this volume were part of the technical conference cited on the cover and title page. Papers were selected and subject to review by the editors and conference program committee. Some conference presentations may not be available for publication. The papers published in these proceedings reflect the work and thoughts of the authors and are published herein as submitted. The publishers are not responsible for the validity of the information or for any outcomes resulting from reliance thereon.

Please use the following format to cite material from this book:

Author(s), "Title of Paper," in The Engineering Reality of Virtual Reality 2013, edited by Margaret Dolinsky, lan E. McDowall, Proceedings of SPIE-IS\&T Electronic Imaging, SPIE Vol. 8649. Article CID Number (2013)

ISSN: 0277-786X

ISBN: 9780819494221

Copublished by

SPIE

P.O. Box 10, Bellingham, Washington 98227-0010 USA

Telephone +1 3606763290 (Pacific Time) · Fax +1 3606471445

SPIE.org

and

IS\&T-The Society for Imaging Science and Technology

7003 Kilworth Lane, Springfield, Virginia, 22151 USA

Telephone +1 7036429090 (Eastern Time) · Fax +1 7036429094

imaging.org

Copyright (C) 2013, Society of Photo-Optical Instrumentation Engineers and The Society for Imaging Science and Technology.

Copying of material in this book for internal or personal use, or for the internal or personal use of specific clients, beyond the fair use provisions granted by the U.S. Copyright Law is authorized by the publishers subject to payment of copying fees. The Transactional Reporting Service base fee for this volume is $\$ 18.00$ per article (or portion thereof), which should be paid directly to the Copyright Clearance Center (CCC), 222 Rosewood Drive, Danvers, MA 01923. Payment may also be made electronically through CCC Online at copyright.com. Other copying for republication, resale, advertising or promotion, or any form of systematic or multiple reproduction of any material in this book is prohibited except with permission in writing from the publisher. The CCC fee code is 0277-786X/13/\$18.00.

Printed in the United States of America.

Paper Numbering: Proceedings of SPIE follow an e-First publication model, with papers published first online and then in print and on CD-ROM. Papers are published as they are submitted and meet publication criteria. A unique, consistent, permanent citation identifier (CID) number is assigned to each article at the time of the first publication. Utilization of CIDs allows articles to be fully citable as soon as they are published online, and connects the same identifier to all online, print, and electronic versions of the publication. SPIE uses a six-digit CID article numbering system in which:

- The first four digits correspond to the SPIE volume number.

- The last two digits indicate publication order within the volume using a Base 36 numbering

system employing both numerals and letters. These two-number sets start with 00, 01, 02, 03, 04, $05,06,07,08,09,0 A, 0 B \ldots 0$, followed by 10-1Z, 20-2Z, etc.

The CID Number appears on each page of the manuscript. The complete citation is used on the first page, and an abbreviated version on subsequent pages. Numbers in the index correspond to the last two digits of the six-digit CID Number. 


\section{Contents}

vii Conference Committee

\section{SESSION 1 WELCOME TO FUTURE TECH 3000}

864902 CalVR: an advanced open source virtual reality software framework [8649-1]

J. P. Schulze, A. Prudhomme, P. Weber, T. A. DeFanti, Univ. of California, San Diego (United States)

864903 CAVE2: a hybrid reality environment for immersive simulation and information analysis [8649-2]

A. Febretti, A. Nishimoto, T. Thigpen, J. Talandis, L. Long, J. D. Pirtle, T. Peterka, A. Verlo, M. Brown, D. Plepys, D. Sandin, L. Renambot, A. Johnson, J. Leigh, Univ. of Illinois at

Chicago (United States)

\section{SESSION 2 CAN I BORROW YOUR SWISS ARMY KNIFE?}

864904 MASCARET: creating virtual learning environments from system modelling [8649-3]

R. Querrec, P. Vallejo, C. Buche, École Nationale d'Ingénieurs de Brest (France)

864905 Employing WebGL to develop interactive stereoscopic 3D content for use in biomedical visualization [8649-4]

S. Johnston, L. Renambot, D. Sauter, Univ. of Illinois at Chicago (United States)

864906 FreeVR: honoring the past, looking to the future [8649-5]

W. R. Sherman, Indiana Univ. (United States); D. Coming, Univ. of Nevada Reno (United States); S. Su, Ball Aerospace and Technologies Corp. (United States)

864907 An industrial approach to design compelling VR and AR experience [8649-6]

S. Richir, Arts et Métiers ParisTech (France); P. Fuchs, Mines ParisTech (France);

D. Lourdeaux, Heudiasyc, CNRS, Univ. de Technologie de Compiègne (France); C. Buche,

R. Querrec, Lab. STICC, CNRS, École Nationale d'Ingénieurs de Brest (France)

864908 3D interactive augmented reality-enhanced digital learning systems for mobile devices [8649-7]

K.-T. Feng, National Chiao Tung Univ. (Taiwan); P.-H. Tseng, National Taipei Univ. of Technology (Taiwan); P.-S. Chiu, J.-L. Yang, C.-J. Chiu, National Chiao Tung Univ. (Taiwan)

SESSION 3 EVERY PICTURE TELLS A STORY, DON'T IT?

8649 OA Using the computer-driven VR environment to promote experiences of natural world immersion [8649-10]

L. A. Frank, Univ. of Illinois at Urbana-Champaign (United States) and Univ. of WisconsinMadison (United States) 
8649 OB One's Colonies: a virtual reality environment of oriental residences [8649-11]

C. Chi, Indiana Univ. (United States)

8649 OC Mrs. Squandertime [8649-12]

J. Anstey, D. Pape, The Univ. at Buffalo (United States)

\section{SESSION 4 DISCOVER SECRET WORLDS}

8649 OD There's an app for that shirt! Evaluation of augmented reality tracking methods on deformable surfaces for fashion design [8649-13]

S. Ruzanka, B. Chang, Rensselaer Polytechnic Institute (United States); K. Behar, Baruch College, CUNY (United States)

8649 OE Augmented reality: past, present, future [8649-14]

L. Inzerillo, Univ. degli Studi di Palermo (Italy)

8649 OF Vroom: designing an augmented environment for remote collaboration in digital cinema production [8649-15]

T. Margolis, T. Cornish, Univ. of California, San Diego (United States)

8649 OG New perspectives and limitations in the use of virtual reality in the rehabilitation of motor disorders [8649-16]

A. De Mauro, A. Ardanza, Vicomtech-IK4 (Spain); E. Monge, F. Molina Rueda, Univ. Rey Juan Carlos (Spain)

PANEL SESSION: ART, SCIENCE, AND IMMERSION: DATA-DRIVEN EXPERIENCE

$8649 \mathrm{OH} \quad$ Art, science, and immersion: data-driven experiences [8649-17]

R. G. West, Univ. of North Texas (United States); L. Monroe, Los Alamos National Lab. (United States); J. Ford Morie, The Univ. of Southern California (United States); J. Aguilera, Adler Planetarium (United States)

\section{SESSION $5 \quad$ VIEWING PORTS OF CALL}

8649 Ol Nomad devices for interactions in immersive virtual environments [8649-18] P. George, Renault Technical Ctr. for Simulation (France), LE2I, CNRS, Arts et Métiers ParisTech (France), and Heudiasyc, CNRS, Univ. de Technologie de Compiègne (France); A. Kemeny, Renault Technical Ctr. for Simulation (France) and LE2I, CNRS, Arts et Métiers ParisTech (France); F. Merienne, J.-R. Chardonnet, LE2I, CNRS, Arts et Métiers ParisTech (France); I. M. Thouvenin, Heudiasyc, CNRS, Univ. de Technologie de Compiègne (France); J. Posselt, E. Icart, Renault Technical Ctr. for Simulation (France)

8649 0J Analysis of tactors for wearable simulator feedback: a tactile vest architecture [8649-19] D. Prater, S. Gilbert, E. Winer, lowa State Univ. (United States) 
8649 OK Use of virtual reality to promote hand therapy post-stroke [8649-20]

D. Tsoupikova, Univ. of Illinois at Chicago (United States); N. Stoykov, Rehabilitation Institute of Chicago (United States); R. Vick, School of The Art Institute of Chicago (United States);

Y. Li, D. Kamper, M. Listenberger, Rehabilitation Institute of Chicago (United States)

$8649 \mathrm{OL}$ Collaborative imaging of urban forest dynamics: augmenting re-photography to visualize changes over time [8649-21]

R. West, Univ. of North Texas (United States); A. Halley, Washington Univ. in St. Louis (United States); J. O'Neil-Dunne, The Univ. of Vermont (United States); D. Gordon, R. Pless,

Washington Univ. in St. Lovis (United States)

\section{INTERACTIVE PAPER SESSION}

8649 OM Integral virtual display for long distance view [8649-22]

K. Shimazu, T. Yendo, Nagaoka Univ. of Technology (Japan)

Author Index 
SPIE-IS\&T/ Vol. $8649864901-6$

Downloaded From: https://www.spiedigitallibrary.org/conference-proceedings-of-spie on 25 Apr 2023 Terms of Use: https://www.spiedigitallibrary.org/terms-of-use 


\title{
Conference Committee
}

\author{
Symposium Chair
}

Gaurav Sharma, University of Rochester (United States)

Symposium Cochair

Sergio R. Goma, Qualcomm Inc. (United States)

Conference Chairs

Margaret Dolinsky, Indiana University (United States)

Ian E. McDowall, Fakespace Labs, Inc. (United States)

Conference Program Committee

Todd Margolis, University of California, San Diego (United States)

Tracy Cornish, University of California, San Diego (United States)

Session Chairs

1 Welcome to Future Tech 3000

Ian E. McDowall, Fakespace Labs, Inc. (United States)

2 Can I Borrow Your Swiss Army Knife?

Margaret Dolinsky, Indiana University (United States)

3 Every Picture Tells a Story, Don't It?

Ian E. McDowall, Fakespace Labs, Inc. (United States)

4 Discover Secret Worlds

Margaret Dolinsky, Indiana University (United States)

Panel Session: Art, Science, and Immersion: Data-Driven Experience Margaret Dolinsky, Indiana University (United States)

5 Viewing Ports of Call

Ian E. McDowall, Fakespace Labs, Inc. (United States) 
SPIE-IS\&T/ Vol. $8649864901-8$

Downloaded From: https://www.spiedigitallibrary.org/conference-proceedings-of-spie on 25 Apr 2023 Terms of Use: https://www.spiedigitallibrary.org/terms-of-use 